\title{
Cytotoxicity and physicochemical characterization of iron-manganese-doped sulfated zirconia nanoparticles
}

This article was published in the following Dove Press journal:

International Journal of Nanomedicine

10 September 2015

Number of times this article has been viewed

\author{
Mohamed Qasim \\ Al-Fahdawi' \\ Abdullah Rasedee ${ }^{1,2}$ \\ Mothanna Sadiq Al-Qubaisi' \\ Fatah H Alhassan ${ }^{3,4}$ \\ Rozita Rosli' \\ Mohamed Ezzat El \\ Zowalaty ${ }^{1,5}$ \\ Seïf-Eddine Naadja ${ }^{6}$ \\ Thomas J Webster ${ }^{7,8}$ \\ Yun Hin Taufiq-Yap ${ }^{3,4}$ \\ 'Institute of Bioscience, ${ }^{2}$ Department \\ of Veterinary Pathology and \\ Microbiology, Faculty of Veterinary \\ Medicine, ${ }^{3}$ Catalysis Science and \\ Technology Research Centre, Faculty \\ of Science, ${ }^{4}$ Department of Chemistry, \\ Faculty of Science, ${ }^{5}$ Biomedical \\ Research Center, Qatar University, \\ Doha, Qatar; ' ${ }^{\circ}$ epartment of Cell \\ and Molecular Biology, Faculty of \\ Biotechnology and Biomolecular \\ Sciences, Universiti Putra Malaysia \\ (UPM), Serdang, Selangor, Malaysia; \\ ${ }^{7}$ Department of Chemical Engineering, \\ Northeastern University, Boston, \\ MA, USA; ${ }^{8}$ Center of Excellence for \\ Advanced Materials Research, King \\ Abdulaziz University, Jeddah, Saudi \\ Arabia
}

Correspondence: Abdullah Rasedee Department of Veterinary Pathology and Microbiology, Faculty of Veterinary Medicine, Universiti Putra Malaysia, 43400 UPM Serdang, Selangor, Malaysia Tel +60389463455

Fax +603 8946 |97|

Email rasedee@upm.edu.my
Abstract: Iron-manganese-doped sulfated zirconia nanoparticles with both Lewis and Brønsted acidic sites were prepared by a hydrothermal impregnation method followed by calcination at $650^{\circ} \mathrm{C}$ for 5 hours, and their cytotoxicity properties against cancer cell lines were determined. The characterization was carried out using X-ray diffraction, thermogravimetric analysis, Fourier transform infrared spectroscopy, Brauner-Emmett-Teller (BET) surface area measurements, X-ray fluorescence, X-ray photoelectron spectroscopy, zeta size potential, and transmission electron microscopy (TEM). The cytotoxicity of iron-manganese-doped sulfated zirconia nanoparticles was determined using 3-(4,5-dimethylthiazol-2-yl)-2,5-diphenyltetrazolium bromide (MTT) assays against three human cancer cell lines (breast cancer MDA-MB231 cells, colon carcinoma HT29 cells, and hepatocellular carcinoma HepG2 cells) and two normal human cell lines (normal hepatocyte Chang cells and normal human umbilical vein endothelial cells [HUVECs]). The results suggest for the first time that iron-manganese-doped sulfated zirconia nanoparticles are cytotoxic to MDA-MB231 and HepG2 cancer cells but have less toxicity to HT29 and normal cells at concentrations from $7.8 \mu \mathrm{g} / \mathrm{mL}$ to $500 \mu \mathrm{g} / \mathrm{mL}$. The morphology of the treated cells was also studied, and the results supported those from the cytotoxicity study in that the nanoparticle-treated HepG2 and MDA-MB231 cells had more dramatic changes in cell morphology than the HT29 cells. In this manner, this study provides the first evidence that iron-manganese-doped sulfated zirconia nanoparticles should be further studied for a wide range of cancer applications without detrimental effects on healthy cell functions.

Keywords: nanopartices, Lewis and Brønsted acidic sites, anticancer applications, HT29 cells, transition metal oxide

\section{Introduction}

Many processes which are very significant to life (such as pharmaceutical and petrochemical processes) have benefited from solid acid enhancers leading to improvements in selectivity and activity. ${ }^{1,2}$ It has been reported that the status of active sites on a material surface, whether it is of Brønsted or Lewis nature, are common factors for promoting bioactivity and bioselectivity. In this respect, the incorporation of powerful acidic anions on the surface of various material supporting structures (such as alumina, silica, and zirconia) has attracted great attention. ${ }^{3}$ Among the most powerful acidic anions, sulfate species doped on the surface of zirconium oxide have generated great potential for a number of significant processes such as organic synthesis. ${ }^{4}$ Nevertheless, the selectivity and activity of nanoparticles of iron $(+3)$-manganese-doped sulfated zirconia can be governed by the effective incorporation of ferric oxide and manganese dioxide as well as sulfate anions into the zirconia skeleton. ${ }^{5}$ They display 
the best catalytic activity toward $n$-butane isomerization under reasonable conditions. ${ }^{6}$

Along the same lines, nanoparticle medications have arisen as a modern research direction for the release of hydrophobic medicines owing to their characteristic gains over colloidal drug transporters. ${ }^{7}$ Generally, transition metal oxides have been commonly employed either as supporters or as promoters to improve physiochemical properties for many reactions. ${ }^{8-11}$ For example, approximately all advanced materials contain an oxide as the active system which shows both hydrogen ion and electron transmission abilities and should be utilized as an enhancer in acid-base reactions as well as electron gain and release reactions. These reductionoxidation processes utilizing metal oxide redox properties have been widely applied as an environmentally friendly process for the full oxidation of polluted ingredients. ${ }^{12-19}$

Moreover, transition metal oxide systems having redox properties are also used for the conversion of organic constituent sustainable and renewable chemicals. ${ }^{20-22}$ The physicochemical properties of transition metal oxides are considered to be a potential factor in carrying out discriminating organic reactions. Meanwhile, the rate-determining step on the surface of such novel materials would be evaluated via the mass of energetic sites in addition to the BraunerEmmett-Teller (BET) surface area with notable improvements in catalytic activity related to increases in BET surface area that comes from smaller particle diameters. Thus, in the emerging field of nanoparticles, the synthesis of transition metal oxide nanoparticles has garnered significant consideration, attributable to unique physical and chemical properties gained for materials at the nanoscale. ${ }^{23,24}$

The surface of zirconia is known to have all of these physicochemical properties. Doping $\mathrm{ZrO}_{2}$ with materials such as ferric, manganese, nickel, platinum, phosphate, and sulfate species has significantly improved its catalytic activity. ${ }^{25-27}$ In particular, iron(+3)-manganese-doped sulfated zirconia has been commonly employed to enhance various lifesupport operations. ${ }^{28-31}$ Additionally, these transition metal oxide materials have a promising future in various ecological decontamination applications such as for sustainable chemical as well as oncological drug applications.

Due to its magnetic properties, iron doping can also impact magnetic properties to aid in the directed treatment of diseases through magnetic force. Moreover, the discovery of novel antitumor agents is largely based on the screening of cytotoxic activity against cancer cell lines in vitro. ${ }^{32,33}$ The therapeutic utilization of nanoparticles for cancer applications often starts via human cell culture testing.
The development of chemical target agents that exploit differences between cancerous and normal cells permits greater specificity for cancer cells with less damage to normal healthy cells. ${ }^{34}$ Although chemotherapy and radiation therapy can induce cancer remission in patients with tumors, a group of malignancies remains a therapeutic challenge due to frequent tumor relapse and chemotherapy resistance..$^{35}$ Thus, there is a continual need to identify drugs which are nontoxic, have few adverse side effects, and might be of great benefit in reducing the dosage of existing chemotherapeutic drugs.

Doxorubicin is one of the best drugs for systemic chemotherapy which works against breast cancer. For colon cancer treatment, oxaliplatin is commonly used, while tamoxifen is the most commonly used drug for liver cancer. ${ }^{33,35}$

The evidence currently available clearly indicates that sulfated zirconia nanoparticles are toxic in vitro for several types of cancer cells including human colorectal carcinoma HT29 cells, human liver carcinoma HepG2 cells, and human breast carcinoma MCF-7 cells. In contrast, normal (noncancerous) human breast carcinoma MCF-10a cells were found to be the least sensitive to sulfated zirconia nanoparticles. ${ }^{36}$

As far as it is known, the present in vitro study is the first report to determine the anticancer properties of iron-manganese-doped sulfated zirconia nanoparticles. The addition of iron will help the directed delivery (via magnetic force) of nanoparticles to cancer sites. Iron(+3)-manganese-doped sulfated zirconia nanoparticles were synthesized in this study via a hydrothermal impregnation method and were characterized using X-ray photoelectron spectroscopy, X-ray diffraction (XRD), thermogravimetric analysis, Fourier transform infrared spectroscopy, BET, X-ray fluorescence, zeta size potential, and transmission electron microscopy (TEM). The toxicity of iron-manganese-doped sulfated zirconia nanoparticles was assessed here against human colon cancer HT29 cells, human breast cancer MDA-MB231 cells, and human liver cancer HepG2 cells in comparison with oxaliplatin, doxorubicin, and tamoxifen, respectively. Normal (noncancerous) human liver Chang cells and normal human umbilical vein endothelial cells (HUVECs) were used as controls.

The results, coupled with in vitro assays, demonstrate much promise for the use of iron(+3)-manganese-doped sulfated zirconia nanoparticles in numerous anticancer applications.

\section{Materials and methods Chemicals and reagents}

Ammonium sulfate, zirconium oxynitrate, and ammonium hydroxide (28\%-30\%) were obtained from Sigma-Aldrich Co. 
(St Louis, MO, USA). The trypsin/ethylenediaminetetraacetic acid (EDTA) solution was purchased from Thermo Fisher Scientific (Waltham, MA, USA). Dimethyl sulfoxide (DMSO), phosphate-buffered saline, 3-(4,5-dimethylthiazol2-yl)-2,5-diphenyltetrazolium bromide (MTT), Dulbecco's Modified Eagle's Medium (DMEM), 95\% ethanol, fetal bovine serum (FBS), trypan blue dye solution, trypsin/EDTA, and antibiotics were purchased from Sigma-Aldrich Co.

\section{Preparation of iron(III) oxide-manganese dioxide-doped sulfated zirconia and $4 \%$ $\mathrm{SO}_{4}^{2-}$}

The iron-manganese-doped sulfated zirconia was prepared via a precipitation and hydrothermal impregnation method. Initially, $5 \mathrm{~g}$ of hydrated zirconium nitrate was dissolved in approximately $150 \mathrm{~mL}$ of deionized water with a dropwise addition of $3.0 \mathrm{~g}$ of $30 \%$ ammonia in $5 \mathrm{~mL}$ of deionized water which resulted in the precipitation. A necessary amount of a $30 \%$ ammonia solution was added in order to maintain a $\mathrm{pH}$ value in the range of 9 to 10 . The precipitate was aged for 24 hours, filtered by a vacuum pump, and washed with approximately $600 \mathrm{~mL}$ of warm deionized water. The precipitate was then dried for approximately 18 hours at $120^{\circ} \mathrm{C} .^{37}$

Hydrated iron(III) nitrate $(0.60 \mathrm{~g})$, tetrahydrated manganese nitrate $\left(\mathrm{Mn}\left(\mathrm{NO}_{3}\right)_{2} \cdot 4 \mathrm{H}_{2} \mathrm{O}\right)(0.130 \mathrm{~g})$, and $\left(\mathrm{NH}_{4}\right)_{2} \mathrm{SO}_{4}$ $(0.230 \mathrm{~g})$ were dissolved in approximately $150 \mathrm{~mL}$ of deionized water. The solution was added dropwise under vigorous stirring into a zirconium oxyhydroxide solution. The mixed solution was left while stirring at room temperature for 6 hours and was then transferred to a closed autoclave reactor to dry in an oven at $150^{\circ} \mathrm{C}$ for 24 hours. Finally, the product was calcined for 5 hours at $650^{\circ} \mathrm{C}$ according to standard procedures. ${ }^{38,39}$

\section{Physicochemical properties of iron- manganese-doped sulfated zirconia- $4 \%$ $\mathrm{SO}_{4}^{2-}$}

X-ray photoelectron spectra were obtained by employing a modified AXIS ULTRA DLD (KRATOS) photoelectron spectrometer, fully furnished with a hemispherical analyzer. For excitation, $\mathrm{AlK} \alpha(1,486.6 \mathrm{eV})$ radiation was applied. The analyzer functioned in the fixed analyzer transmission mode at a pass energy of $40 \mathrm{eV}$. The $\mathrm{X}$-ray gun was activated at an emission current of $4 \mathrm{~mA}$ with $15 \mathrm{kV}$ of stepping-up voltage. Samples were pretreated under a vacuum $\left(1 \times 10^{-9}\right.$ Torr $)$ at $22 \pm 2^{\circ} \mathrm{C}$ for 2 hours before analysis. The base pressure of the analyzer chamber was $1 \times 10^{-9}$ Torr; throughout the collection of information, the pressure was constant at $<1 \times 10^{-9}$ Torr.
The binding energy matching to $\mathrm{C} 1 \mathrm{~s}, \mathrm{Zr} 3 \mathrm{~d}, \mathrm{Fe} 2 \mathrm{p}, \mathrm{Mn} 2 \mathrm{p}$, $\mathrm{S} 2 \mathrm{p}$, and $\mathrm{O} 1 \mathrm{~s}$ was determined. All binding energies are relative to the $\mathrm{C} 1 \mathrm{~s}$ peak, taken as $284.5 \mathrm{eV}$.

The thermal strength of the iron(III)-manganesedoped sulfated zirconia-4\% $\mathrm{SO}_{4}{ }^{2-}$ was investigated via a Mettler Toledo TGA-SDTA apparatus (Pt crucibles, $\mathrm{Pt} / \mathrm{Pt}-$ $\mathrm{Rh}$ thermocouple), with a purge gas (nitrogen) flow rate of $30 \mathrm{~mL} \mathrm{~min}{ }^{-1}$ and a heating rate of $10^{\circ} \mathrm{C} \mathrm{min}^{-1}$ from room temperature to $1,000^{\circ} \mathrm{C}$.

To determine functional groups on the surface of the iron(III)-manganese-doped sulfated zirconia-4\% $\mathrm{SO}_{4}{ }^{2-}$, Fourier transform infrared analysis was performed with a PerkinElmer model 100 series spectrometer.

The total surface area of the iron(III)-manganese-promoted sulfated zirconia-4\% $\mathrm{SO}_{4}{ }^{2-}$ was evaluated via nitrogen adsorption at $-196^{\circ} \mathrm{C}$. The evaluation was performed using a Thermo Fisher Scientific (model: Surfer analyzer) nitrogen adsorption-desorption analyzer.

$\mathrm{X}$-ray fluorescence has been widely accepted as a nondestructive method used for identifying and assessing the amount of metal or metal oxides incorporated in powders. Metallic materials should be transformed into a powder to yield an identical shape, while substances with fine particles should be compressed to establish the size of the particles and pressed into tablets for analysis.

Powder XRD characterization was performed utilizing a Shimadzu diffractometer (model XRD 6000). A diffractometer employing $\mathrm{Cu}-\mathrm{K} \alpha$ radiation generated by a Philips glass diffraction X-ray tube broad focus $2.7 \mathrm{~kW}$ type was used at ambient temperature. The crystallite size (T) of the samples was calculated by the Debye-Scherrer relationship according to standard procedures: ${ }^{40-42}$

$$
\mathrm{T}=0.9 \lambda /(\beta \cos \theta),
$$

where $\lambda$ is the incident $X$-ray wavelength, $\beta$ is the full width at half-maximum, and $\theta$ is the diffraction angle.

TEM (Hitachi H-7100) was employed to determine the inner finer structure of the crystal. For TEM analysis, the powder was disseminated in deionized water, placed onto carbon-coated copper grids on a filter paper, and dried at room temperature.

The zeta potential of the iron(III)-manganese-doped sulfated zirconia nanoparticle dispersions $(1 \mu \mathrm{g}$ of sulfated zirconia nanoparticles dispersed in $1 \mathrm{~mL}$ of ultra-deionized water) was characterized using a Zetasizer Nano ZS instrument (Malvern Instruments, Malvern, UK) with dynamic light scattering. 


\section{Cell culture}

Five human cell lines were obtained from the American Type Culture Collection ([ATCC] Manassas, VA, USA). The cell lines were MDA-MB231(ATCC ${ }^{\circledR}$ HTB-26 $^{\text {TM }}$ ), HT29 (ATCC ${ }^{\circledR}$ HTB-38 ${ }^{\mathrm{TM}}$ ), HepG2 (ATCC ${ }^{\circledR}$ HB-8065 ${ }^{\mathrm{TM}}$ ), HUVEC (ATCC ${ }^{\circledR}$ CRL-1730 ${ }^{\mathrm{TM}}$ ), and Chang (ATCC ${ }^{\circledR}$ CCL-13 ${ }^{\mathrm{TM}}$ ), which were all characterized as virus-negative. Cells were cultured in DMEM supplemented with 10\% FBS and 1\% antibiotics (100 U/mL penicillin) in an incubator at $37^{\circ} \mathrm{C}$ in the presence of $5 \% \mathrm{CO}_{2}$.

\section{MTT assays}

Before applying the iron-manganese-doped sulfated zirconia nanoparticles to cell culture, the nanoparticles were well distributed in DMEM with 10\% heated inactivated FBS freshly added using ultrasound treatment in order to obtain nanoparticle colloidal suspension. However, according to previous studies, ${ }^{36,43}$ these nanoparticles exhibited stable chemical and thermal properties.

MTT assay was performed as previously described. ${ }^{34}$ In brief, cells were plated at a density of $1 \times 10^{4}$ cells per well by adding $200 \mu \mathrm{L}$ of cell suspension at $5 \times 10^{4}$ cells $/ \mathrm{mL}$ into each well of a 96-well tissue culture plate. Test compounds were added immediately before incubation. Test compounds were iron-manganese-doped sulfated zirconia nanoparticles at different concentrations ranging from $7.8 \mu \mathrm{g} / \mathrm{mL}$ to $500 \mu \mathrm{g} / \mathrm{mL}$ or the chemotherapeutic agents (oxaliplatin for HT29 cells, doxorubicin for MDA-MB231 cells, and tamoxifen for HepG2 cells, Chang cells, and HUVECs) at concentrations ranging from $0.156 \mu \mathrm{g} / \mathrm{mL}$ to $10.0 \mu \mathrm{g} / \mathrm{mL}$. The plates were incubated at $37^{\circ} \mathrm{C}$ in the presence of $5 \% \mathrm{CO}_{2}$ for 72 hours. After incubation with compounds, the medium was aspirated and cells were washed three times with PBS to ensure that all test compounds were removed and then replaced with fresh medium. Then, $200 \mu \mathrm{L}$ of the MTT solution was added to every well and incubated for 4 to 6 hours at $37^{\circ} \mathrm{C}$ with $5 \%$ $\mathrm{CO}_{2}$. The MTT-containing medium was gently removed, and replaced with DMSO $(200 \mu \mathrm{L}$ per well) to dissolve the formed formazan crystals. The plates were read at $570 \mathrm{~nm}$ on a microtiter plate reader. For each compound tested, the $\mathrm{IC}_{50}$ values (that is, the concentration of drug needed to inhibit cell growth by $50 \%$ ) were determined from the dose-response curves for each cell line.

\section{Microscopic examination of cell morphology}

HepG2 cells, HT29 cells, MDA-MB231 cells, Chang cells, and HUVECs $\left(1 \times 10^{4}\right.$ cells per well $)$ were seeded in six-well plates. After cells were exposed to iron-manganese-doped sulfated zirconia nanoparticles for 72 hours, at $\mathrm{IC}_{50}$ concentrations calculated from the MTT results, general cellular morphology and membrane changes were examined via a light inverted microscope.

All experiments were completed in triplicate and repeated at least three different times.

\section{Results and discussion}

Figure 1 illustrates the X-ray photoelectron spectra of iron(III)-manganese-doped sulfated zirconia- $4 \% \mathrm{SO}_{4}{ }^{2-}$. This material exhibited photoelectron lines at 180.7 and $531.5 \mathrm{eV}$ attributed to $\mathrm{Zr} \mathrm{3d5/2}$ and oxygen 1s levels, respectively. These photoelectron peaks taken together are expected to be due to $\mathrm{ZrO}_{2}{ }^{44}$ The higher binding energy species $(186.0 \mathrm{eV})$ matched that of $\mathrm{Zr}^{4+}$ components attached to the more attractive species. A total lack of impact on the shape of the $\mathrm{Zr} 3 \mathrm{~d}$ peak is very significant and suggests the different strengths and surroundings of the interfaces between the $\mathrm{SO}_{4}{ }^{2-}$ species and the $\mathrm{ZrO}_{2}$ for $\left(\mathrm{NH}_{4}\right)_{2} \mathrm{SO}_{4}$ hydrothermal impregnation at the amount of $4 \% \mathrm{SO}_{4}{ }^{2-} .45,46$ The $\mathrm{S} 2 \mathrm{p}$ photoelectron lines appeared at approximately $168.4 \mathrm{eV}$ (Figure 1C) and indicate the presence of sulfur ions $(+6)$ in agreement with the relative amount to $\mathrm{S}^{6+}$ in sulfates anions and in agreement with a previous research article which performed analysis regarding sulfate group-doped $\mathrm{ZrO}_{2}$ catalysts. ${ }^{46}$ Figure $1 \mathrm{D}$ shows the $\mathrm{X}$-ray photoelectron spectrum of iron(3+)-manganese-doped sulfated $\mathrm{ZrO}_{2}$ in the region of iron $2 \mathrm{p}$. The iron(3+) $2 \mathrm{p} 3 / 2$ and $2 \mathrm{p} 1 / 2$ photoelectron emissions located at approximately 711.0 and $723.5 \mathrm{eV}$, respectively, support the presence of $\mathrm{Fe}_{2} \mathrm{O}_{3}$ at the surface of the iron(3+)-manganese-doped sulfated $\mathrm{ZrO}_{2}$. Moreover, the spectrum is a clear verification of the presence of iron $(+3)$ that is almost similar to the $\mathrm{Fe}_{2} \mathrm{O}_{3}$ spectrum. ${ }^{40,47}$ Mn photoelectron lines could be distinguished only with a rather deprived noisy signal. Figure 1E depicts the photoelectron peaks of the iron(3+)-manganese-doped sulfated $\mathrm{ZrO}_{2}$ substance in the region of the $2 \mathrm{p}$ level of $\mathrm{Mn}$. Hence, the manganese photoelectron emission of 2 p3/2 and $2 \mathrm{p} 1 / 2$ energy levels was detected at approximately 643.0 and $652.8 \mathrm{eV}$, respectively, which confirms the presence of manganese oxide on the surface of iron(3+)-manganese-doped $\mathrm{SO}_{4} / \mathrm{ZrO}_{2}$.

Figure 2 displays the thermogravimetric graph of FeMn$\mathrm{SO}_{4} / \mathrm{ZrO}_{2}$ and the weight lost, determined from thermogravimetric analysis, which matched well with that estimated for the degradation of uncalcined FeMn- $\mathrm{SO}_{4} / \mathrm{ZrO}_{2} \cdot{ }^{48}$ Hence, the thermal procedures for uncalcined FeMn-SO $\mathrm{SO}_{4} / \mathrm{ZrO}_{2}$ below $600^{\circ} \mathrm{C}$ were assigned to the removal of physisorbed water, a mixture of nitrous oxide gases, and transformation processes of zirconyl oxyhydroxide to $\mathrm{ZrO}_{2}$. In addition, the 

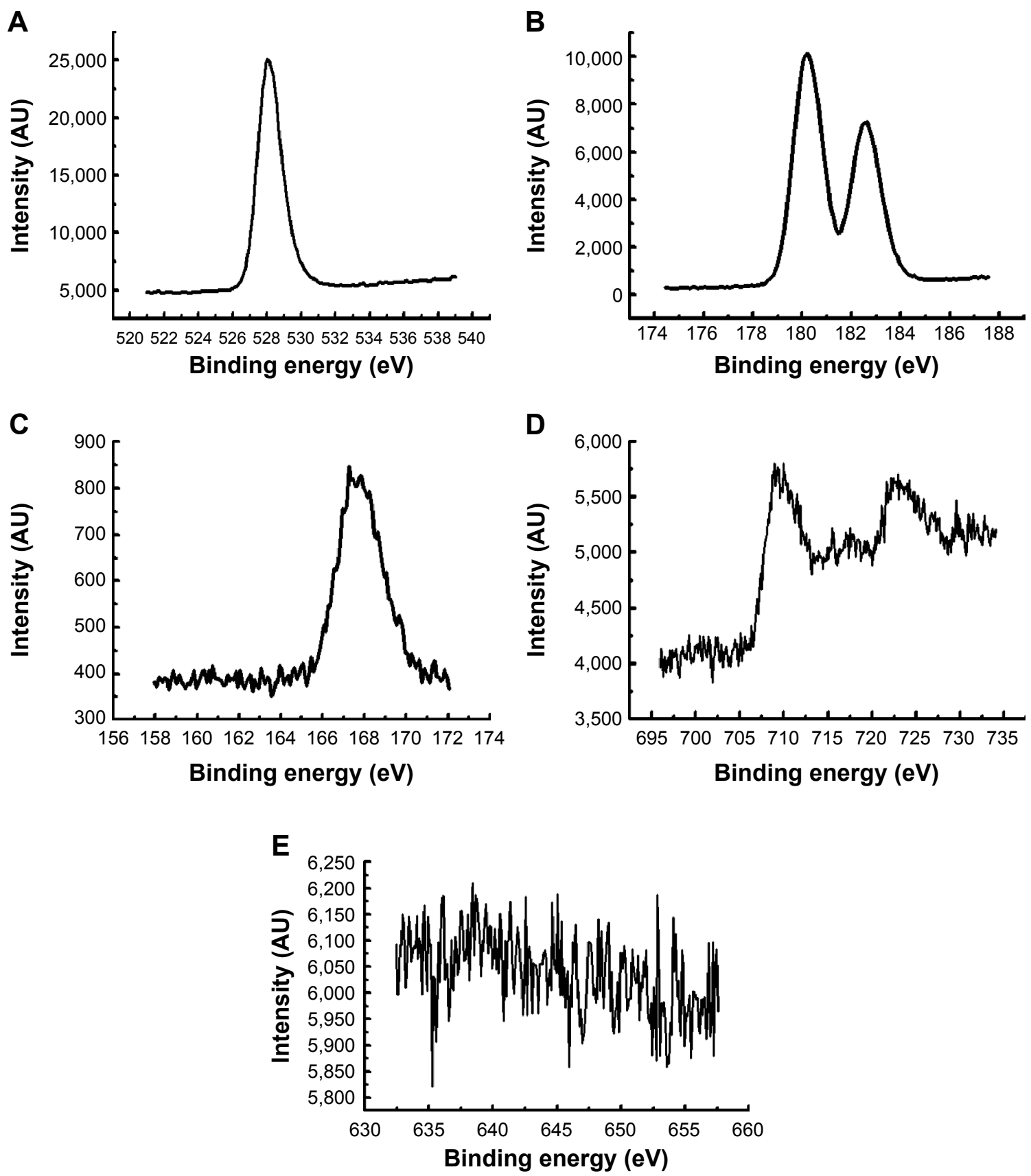

Figure I X-ray photoelectron spectra of iron(+3)-manganese-promoted sulfated zirconia.

Notes: (A) $\mathrm{O}^{2-}(\mathrm{Is})$; (B) $\mathrm{Zr}^{4+}(3 \mathrm{~d} 5 / 2)$; (C) $\mathrm{Fe}^{3+}$ (S 2p); (D) for Fe(III) (2p3/2, 2pl/2); and (E) $\mathrm{Mn}^{4+}(2 \mathrm{p} 3 / 2,2 \mathrm{pl} / 2)$.

second stage of weight loss started approximately $660^{\circ} \mathrm{C}$ and was completed at $950^{\circ} \mathrm{C}$, which is attributed to the breakdown of the $\mathrm{SO}_{4}{ }^{2-}$ anions into sulfur dioxide gas. ${ }^{49}$

Figure 3 shows the Fourier transform infrared spectrum of iron(III)-manganese-doped sulfated zirconia- $4 \% \mathrm{SO}_{4}{ }^{2-}$, and, accordingly, the existence of sulfate species is recognized by the peak which appeared approximately $1,230-1,065$ $\mathrm{cm}^{-1}$, which is attributed to the vibration frequency of both the asymmetric and symmetric stretching of the $\mathrm{O}=\mathrm{S}=\mathrm{O}$ and O-S-O groups, respectively. ${ }^{50,51}$ Furthermore, the absence of peaks approximately $1,450 \mathrm{~cm}^{-1}$ confirmed the existence of polynuclear sulfate in the sample as verified by the absence of bands at approximately $1,440 \mathrm{~cm}^{-1}$, whereas the bending and stretching of vibration bands of the - $\mathrm{OH}$ groups were present in the sample, located at approximately $1,625 \mathrm{~cm}^{-1}$ and $3,325 \mathrm{~cm}^{-1}$, respectively. The manifestation of these peaks in spite of high-temperature calcination indicates the presence of Brønsted acidic active sites in the surface sample.

The BET surface area as well as the pore-size measurements for the iron(III)-manganese-promoted sulfated 


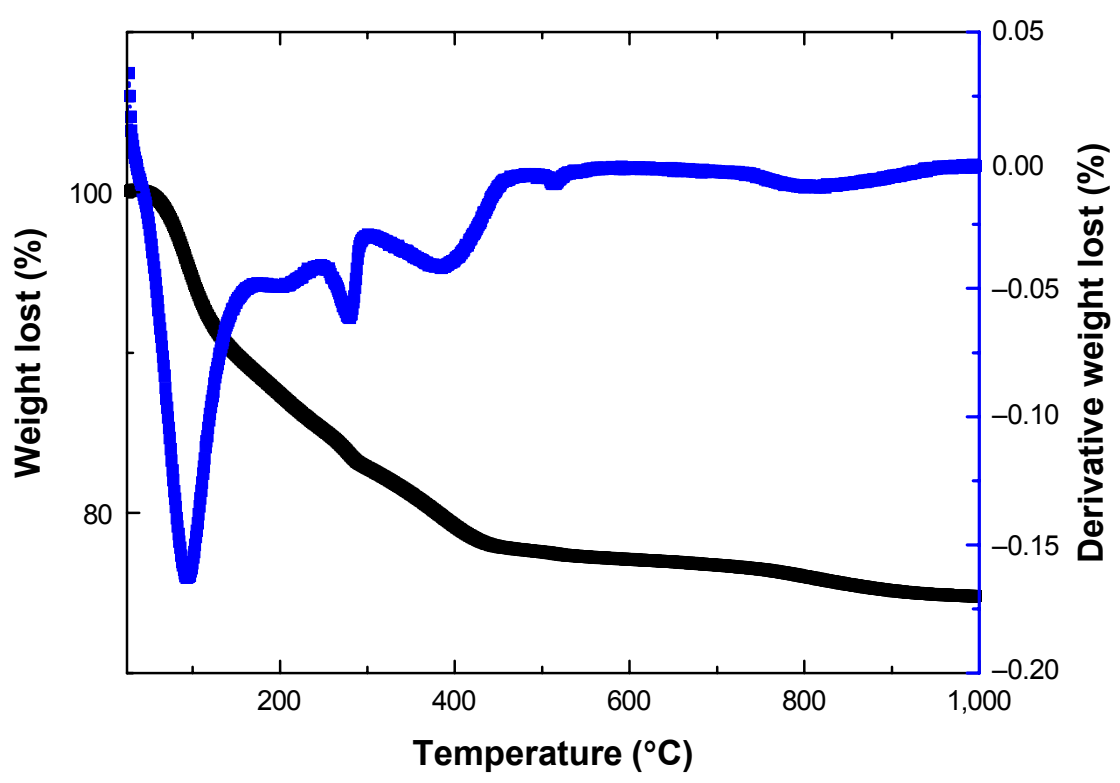

Figure 2 Thermogravimetric analysis-differential temperature curves thermograph of the iron(+3)-manganese-promoted sulfated zirconia sample.

zirconia-4\% $\mathrm{SO}_{4}{ }^{2-}$ via the BET method were found to be $57.0 \mathrm{~m}^{2} / \mathrm{g}$ and $39 \mathrm{~nm}^{3}$, respectively. It was noticed that the incorporation of ferric, manganese, and sulfate anions as promoters on the surface of $\mathrm{ZrO}_{2}$ resulted in an increase in BET surface area and the pore size of iron(III)-manganesedoped sulfated zirconia- $4 \% \mathrm{SO}_{4}{ }^{2-}$ samples. This improvement in the physicochemical properties permitted the reacted materials to be in proximity of acid sites; hence nanoparticles of iron(III)-manganese-doped sulfated zirconia-4\% $\mathrm{SO}_{4}^{2-}$ might have the best activity compared to the sulfated zirconia.

The chemical composition of the iron(III)-manganesedoped sulfated zirconia- $4 \% \mathrm{SO}_{4}{ }^{2-}$ sample was determined using Shimadzu X-ray fluorescence with a Rayny EDX-720 spectrometer according to procedures utilized by others. ${ }^{52,53}$ The amount of metals and nonmetals incorporated into the sample were found to be ferric $1.624 \% \pm 0.15 \%$, manganese $0.497 \% \pm 0.07 \%$, and zirconium $77.7 \% \pm 0.03 \%$, and the rest might have been sulfur and oxygen.

The XRD pattern (as shown in Figure 4) of the iron(III)manganese-doped sulfated zirconia-4\% $\mathrm{SO}_{4}{ }^{2-}$ sample contained a barely tetragonal zirconia phase located at $2 \theta=30.3^{\circ}, 35.4^{\circ}, 50.2^{\circ}$, and $60.2^{\circ}$ (JCPDS file number 00-050-10589 - zirconium oxide). ${ }^{54}$ However, the diffraction line conforming to the monoclinic phase was not apparent in the iron(III)-manganese-doped sulfated

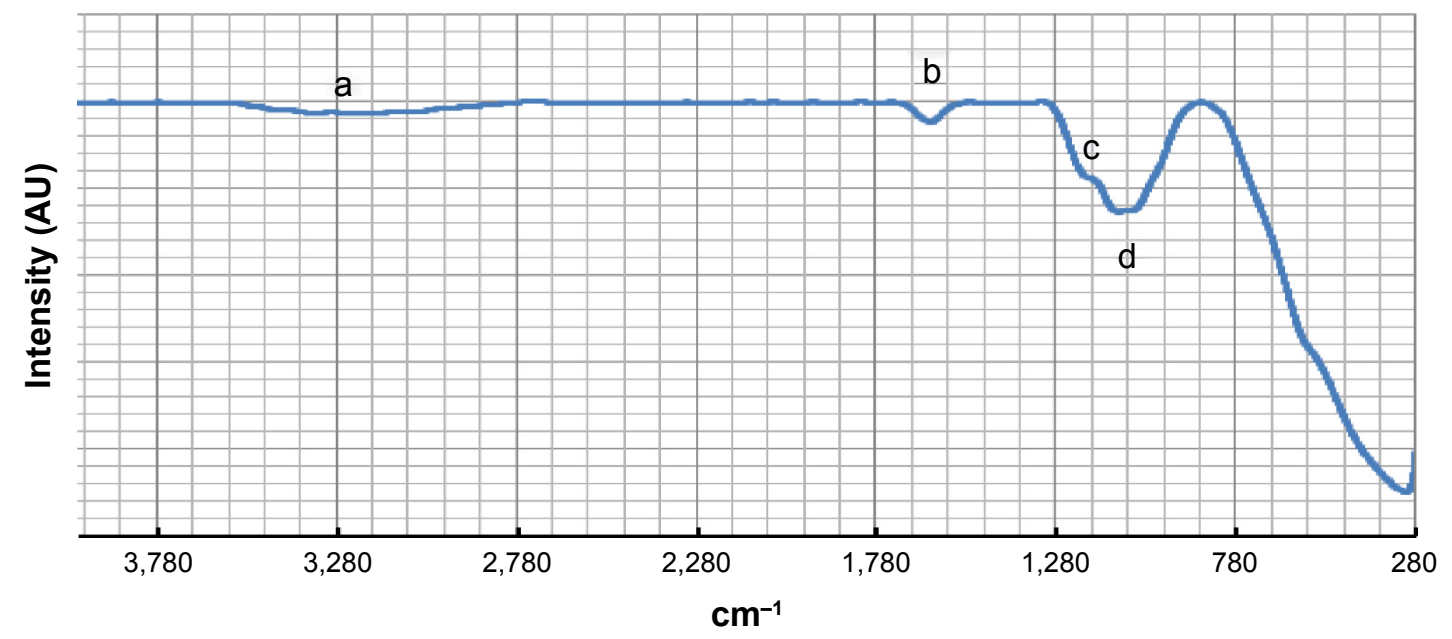

Figure 3 Fourier transform infrared spectrum of iron(+3)-manganese-promoted sulfated zirconia sample.

Notes: (a) Stretching and (b) bending of the $\mathrm{OH}$ group; (c) symmetric stretching of the $\mathrm{O}-\mathrm{S}-\mathrm{O}$ bond; and (d) asymmetric stretching frequency of the $\mathrm{O}=\mathrm{S}=\mathrm{O}$ bond. 


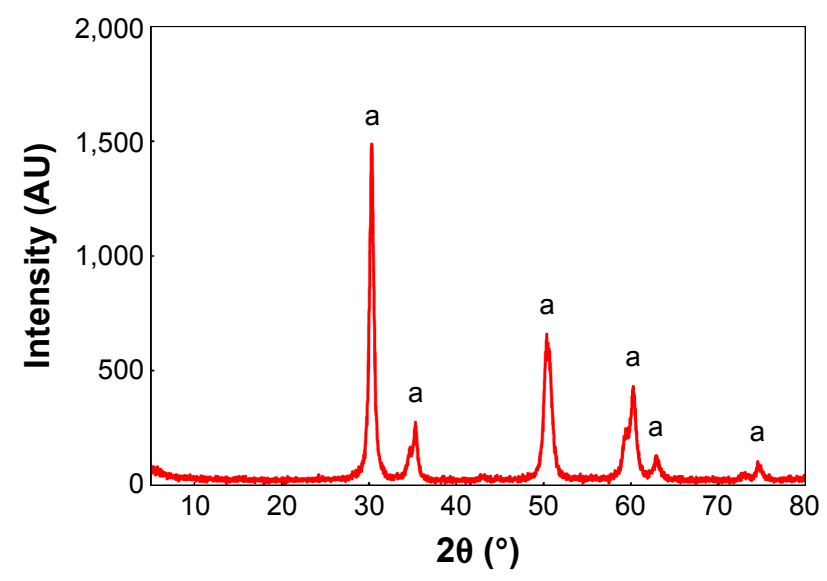

Figure 4 X-ray diffraction pattern of the $\mathrm{Fe}^{3+}-\mathrm{Mn}^{4+}-\mathrm{SO}_{4} / \mathrm{ZrO}_{2}$ sample calcined at $650^{\circ} \mathrm{C}$ for 5 hours.

Note: (a) Tetragonal phase of zirconia.

zirconia-4\% $\mathrm{SO}_{4}{ }^{2-}$ XRD pattern, indicating an equilibrium in the tetragonal phase in the crystal system. The nonappearance of specific diffraction lines corresponding to ferric oxide and manganese dioxide suggests that these oxides were well dispersed on the surface of the support. The dispersion of ferric oxide and manganese dioxide nanoparticles enhanced the equilibrium of the tetragonal phase, hence generated higher surface area. ${ }^{55}$ The size of the iron(III)-manganese-doped sulfated zirconia-4\% $\mathrm{SO}_{4}{ }^{2-}$ crystal was evaluated using the Debye-Scherrer equation and was found to be $12.7 \mathrm{~nm}$.

The shape and size of the crystal and the extent of dispersion of iron(III)-manganese-doped sulfated zirconia- $4 \%$ $\mathrm{SO}_{4}{ }^{2-}$ nanoparticles were examined using TEM. The TEM image of iron-manganese-doped sulfated zirconia nanoparticles is displayed in Figure 5. It was obvious that the nanoparticle crystals were a nearly tetragonal crystal system with sizes ranging from 10.22 to $15.07 \mathrm{~nm}$ with an average size of $12.5 \mathrm{~nm}$. Moreover, a majority of the iron(III)manganese-doped sulfated zirconia- $4 \% \mathrm{SO}_{4}{ }^{2-}$ nanoparticles agglomerated, while a few were detached. ${ }^{56,57}$

Zeta potential is a measure of the effective electric charge on a nanoparticle surface. The magnitude of the zeta potential provides information about particle stability, thus zeta potentials exhibiting increased stability due to a larger electrostatic repulsion between particles. The zeta potential for the $\mathrm{Fe}^{3+}-\mathrm{Mn}^{4+}-\mathrm{SO}_{4} / \mathrm{ZrO}_{2}$ nanoparticle suspensions was found to be $15.0 \pm 4.56 \mathrm{mV}$. This result may indicate that $\mathrm{Fe}^{3+}-\mathrm{Mn}^{4+}-\mathrm{SO}_{4} / \mathrm{ZrO}_{2}$ nanoparticles tend to agglomerate in deionized and double-distilled water. It verifies that these nanoparticles have low electrostatic repulsion properties and incipient instability.

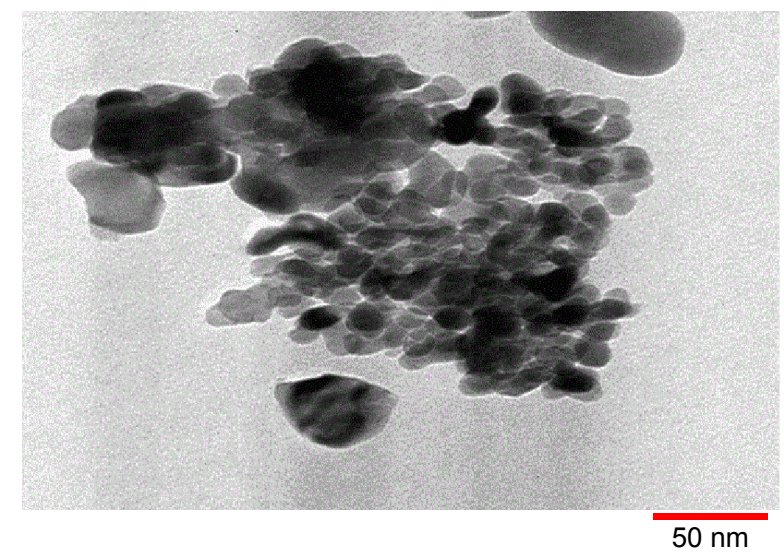

Figure 5 Transmission electron microscopy image of the $\mathrm{Fe}^{3+}-\mathrm{Mn}^{4+}-\mathrm{SO}_{4} / \mathrm{ZrO}_{2}$ sample calcined at $650^{\circ} \mathrm{C}$ for 5 hours.

\section{Cellular sensitivity of cancer and normal cells to iron-manganese-doped sulfated zirconia nanoparticles}

Three human cancer cell lines, estrogen receptor-negative (ER-) MDA-MB-231 cells, colon cancer HT29 cells, and liver cancer HepG2 cells, were used to determine the cytotoxicity of iron-manganese-doped sulfated zirconia nanoparticles. Non-tumorous human liver Chang cells and HUVECs have been used as controls in many studies and were chosen here to determine the selectivity of our formulated nanoparticles. The survival of five human-derived cells after treatment with the iron-manganese-doped sulfated zirconia nanoparticles and chemotherapeutic agents after 72 hours was determined. The responses of cells to increasing concentrations of the test compounds are shown in Figure 6. The results showed a decreased inhibition of both HepG2 and MDA-MB231 cell lines upon low nanoparticle concentrations, with a tapering response intensity as the concentrations of nanoparticles increased. The MTT assay showed a concentration-dependent suppression effect of nanoparticles on cell viability, with higher reduction seen in MDA-MB231 cells.

Following 72 hours of incubation with the nanoparticles at a concentration of $31 \mu \mathrm{g} / \mathrm{mL}, \mathrm{HT} 29, \mathrm{HepG} 2$, and MDAMB-231 cells retained $68 \%, 55 \%$, and $44 \%$ viability, respectively, indicating a decrease in cell growth by $32 \%, 45 \%$, and $56 \%$ for the HT29, HepG2, and MDA-MB-231 cells, respectively. In contrast, normal human HUVECs and Chang cells which were similarly treated with nanoparticles showed a less than $7 \%$ decrease in growth, thereby retaining $93 \%$ viability (Figure 6). An insignificant decrease in growth of HUVECs as compared to considerably higher values seen in normal liver Chang cells indicated that the iron-manganese-doped sulfated zirconia nanoparticles exhibited low toxicity toward 
normal endothelial cells and significantly higher toxicity toward cancer cells and normal liver cells. The $\mathrm{IC}_{50}$ values of nanoparticles after 72 hours of treatment ranged between 25 and $50 \mu \mathrm{g} / \mathrm{mL}$ for MDA-MB231 and HepG2 cell lines, while it was found to be significantly higher $(194 \mu \mathrm{g} / \mathrm{mL})$ for the normal HUVECs (Table 1). The iron-manganese-doped sulfated zirconia nanoparticles showed lower $\mathrm{IC}_{50}$ values for the liver HepG2 $(41 \mu \mathrm{g} / \mathrm{mL})$ cancer cells compared to the normal liver Chang cells $(95 \mu \mathrm{g} / \mathrm{mL})$.

These present results suggest that the present nanoparticles may have strong potential as an anticancer agent. These findings mirror those of a recent study which demonstrated the anticancer potentials of sulfated zirconia nanoparticles on the same two cell lines (HT29 and HepG2 cells) following similar treatments. ${ }^{36}$

In liver cancer HepG2 cells and normal liver Chang cells, tamoxifen did not show selectivity in targeting cancer
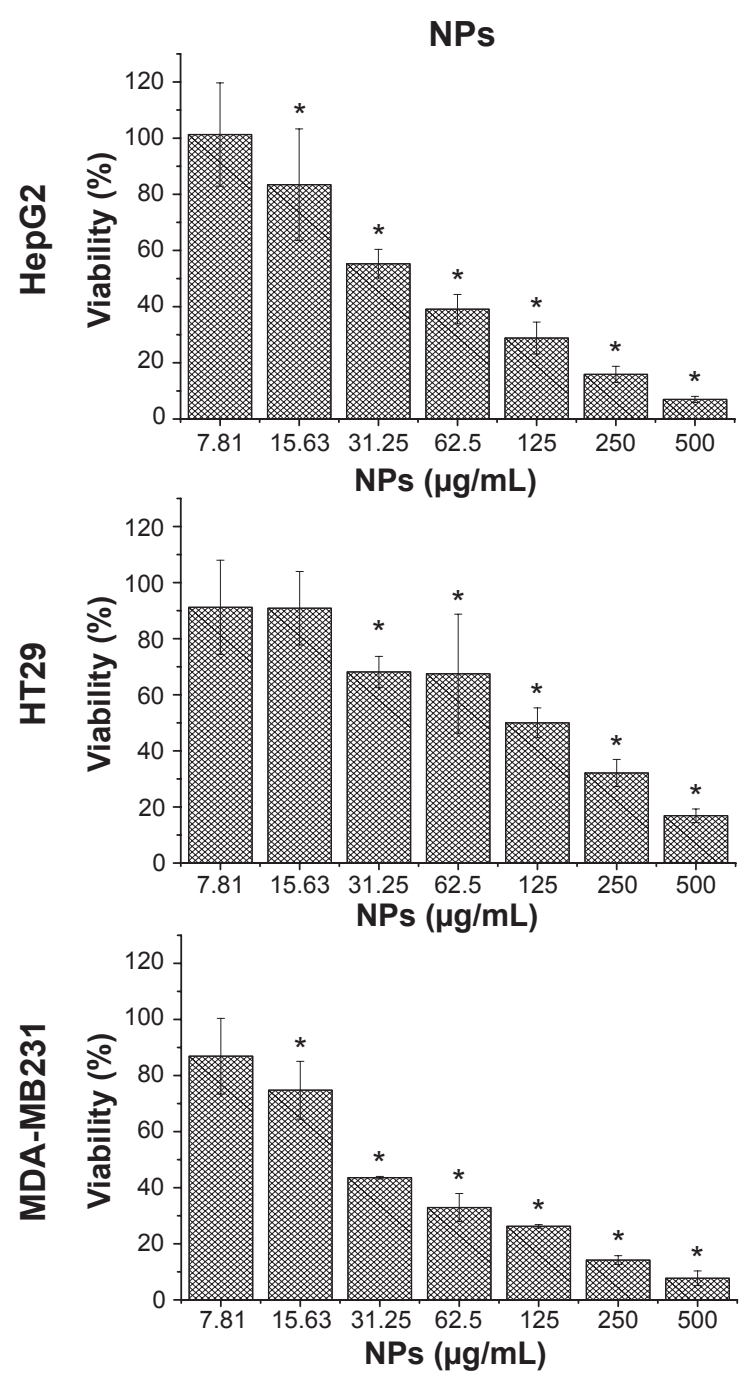

Figure 6 (Continued) cells. Tamoxifen, doxorubicin, and oxaliplatin incubation resulted in concentration-dependent toxicities on both cancer and normal cells. However, the sensitivity of the cells to chemotherapies was considerably different.

\section{Morphological examination of treated cells}

Figure 7 shows that healthy cells remained elongated, whereas dying or dead cells became rounded and lost their adhesion to culture plates. Inverse microscopy performed after 72 hours of challenges to MDA-MB231, HT29, and HepG2 cells with the iron-manganese-doped sulfated zirconia nanoparticles at 28,125 , and $41 \mu \mathrm{g} / \mathrm{mL}$, respectively, revealed dramatic morphological changes. Cellular extensions were detected; cells were rounded and partially detached from the culture flask, and cellular membranes showed extensive blebbing, especially in both MDA-MB231 and HepG2 cell lines.
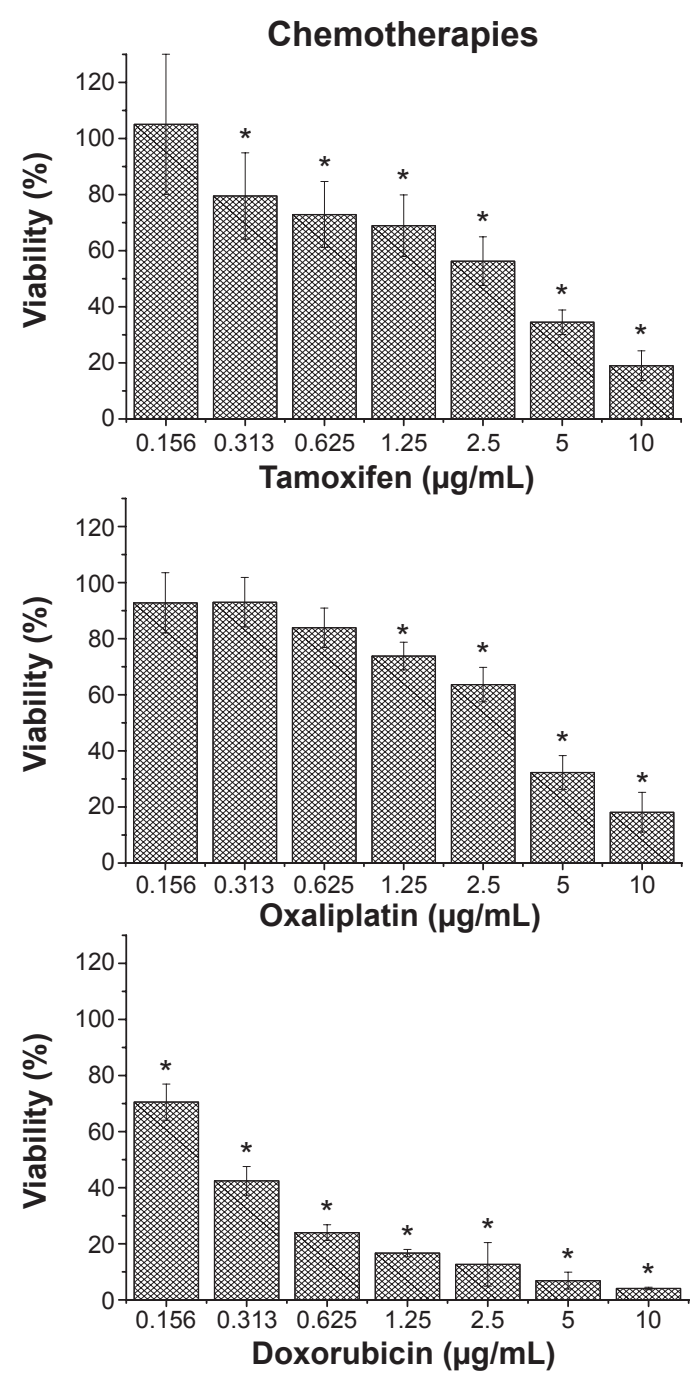

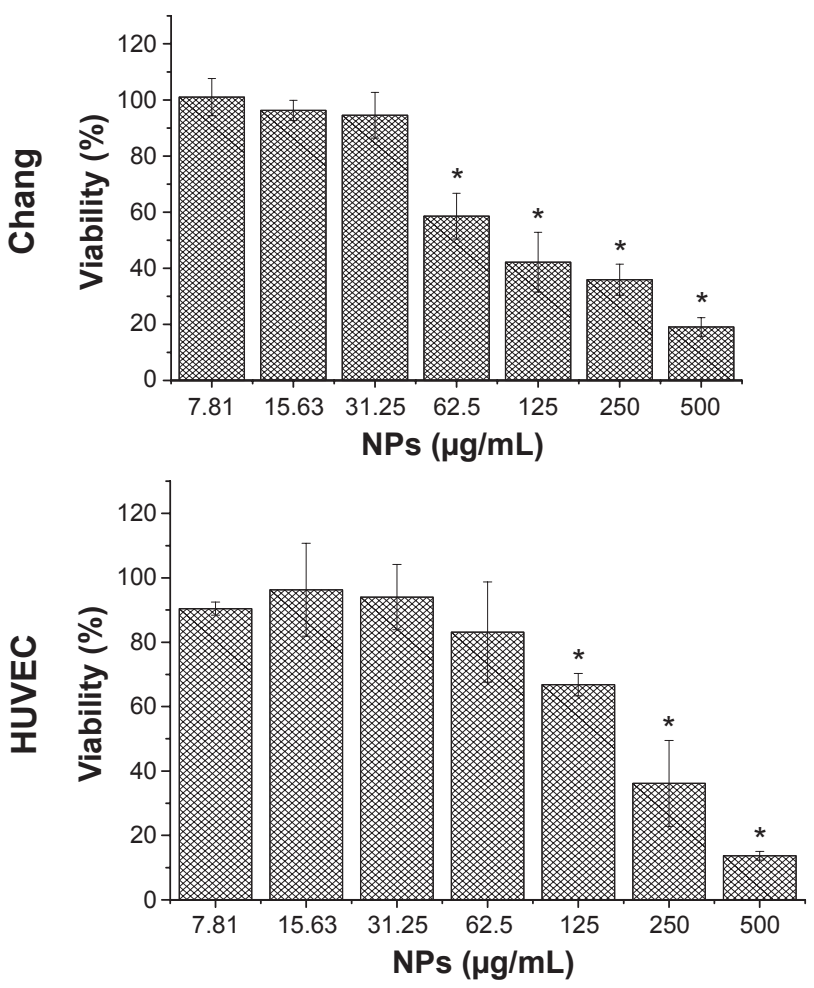

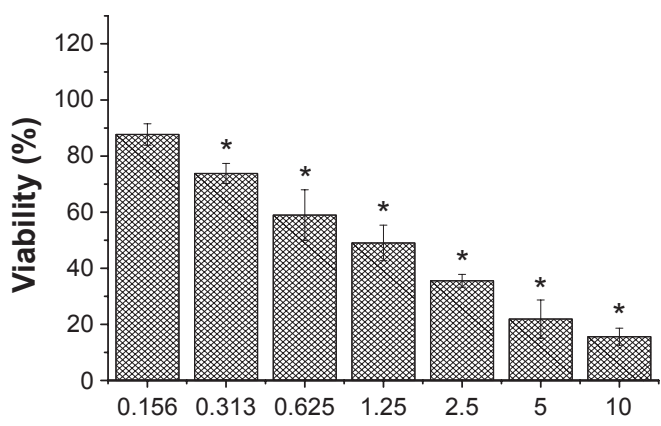

Tamoxifen $(\mu \mathrm{g} / \mathrm{mL})$

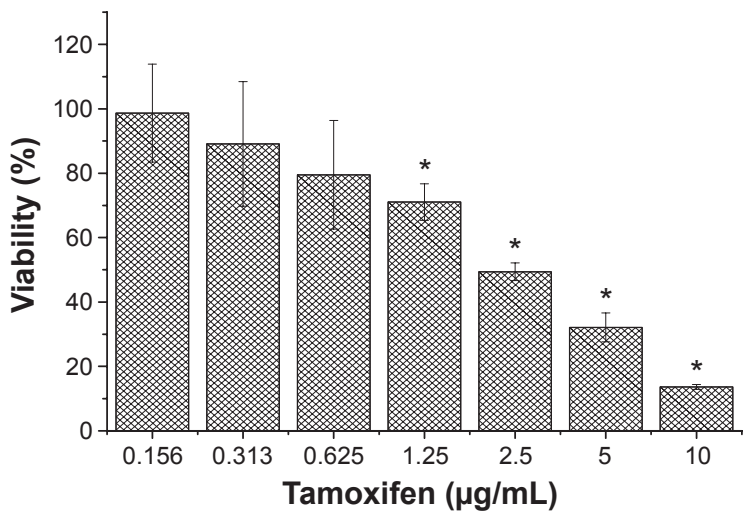

Figure 6 Iron-manganese-promoted sulfated zirconia NP and chemotherapeutic effects on the viability of treated cells, which were evaluated through mitochondrial activity using a 3-(4,5-dimethylthiazol-2-yl)-2,5-diphenyltetrazolium bromide assay.

Notes: Mean \pm standard deviation ( $n=3$ wells/treatment). $* P<0.05$ compared with the untreated cells.

Abbreviations: HUVEC, human umbilical vein endothelial cell; NP, nanoparticle.

In fact, incubation with the iron-manganese-doped sulfated zirconia nanoparticles resulted in a deterioration of the monolayer and loosening of colon cancer HT29 cells less than that seen in other cancer cell lines. The normal liver Chang cells had lost their normal flat morphology and had become spherical. Iron-manganese-doped sulfated zirconia nanoparticle treatment, at $95 \mu \mathrm{g} / \mathrm{mL}$ and $193 \mu \mathrm{g} / \mathrm{mL}$, caused drastic changes in both normal Chang cells and HUVECs, respectively. Some normal cells retained their normal shape and formed a monolayer. After treatment with iron-manganese-promoted sulfated zirconia nanoparticles, the HT29 cells were more confluent and adherent to their surface than HepG2 and MDA-MB231 cells (Figure 7).

\section{Conclusion}

This study shows that the prepared ferric (III)- manganesepromoted sulfated zirconia nanoparticles possessed advanced physicochemical properties. The magnitude of the zeta potential indicates that the low degree of electrostatic repulsion conferred its low stability. The MTT and morphological assays used to evaluate the cytotoxicity of iron-manganesedoped sulfated zirconia nanoparticles against HepG2 and MDA-MB-231 cell lines showed that the nanoparticles were significantly cytotoxic to these cells in a dose-dependent manner, and considerably less cytotoxic toward normal Chang cells and HUVECs. Human colon cancer HT29 cells showed the highest resistance to the nanoparticles among

Table I Comparison of $\mathrm{IC}_{50}$ values for HepG2 cells, HT29 cells, MDD-MB23I cells, Chang cells, and HUVECs obtained from MTT assay following exposure to iron-manganese-promoted sulfated zirconia nanoparticles and chemotherapies for 72 hours

\begin{tabular}{lll}
\hline Cells & $\begin{array}{l}\text { Iron-manganese-promoted sulfated } \\
\text { zirconia nanoparticles }(\mu \mathbf{g} / \mathbf{m L})\end{array}$ & $\begin{array}{l}\text { Chemotherapies } \\
(\mu \mathrm{g} / \mathbf{m L})\end{array}$ \\
\hline HT29 & 125.31 & 3.59 (oxaliplatin) \\
MDA-MB23I & 28.06 & 0.27 (doxorubicin) \\
HepG2 & 41.26 & 3.22 (tamoxifen) \\
Chang & 95.13 & 1.19 (tamoxifen) \\
HUVECs & 193.88 & 2.47 (tamoxifen) \\
\hline
\end{tabular}

Abbreviations: HUVECs, human umbilical vein endothelial cells; $I_{50}$, concentration of drug needed to inhibit cell growth by 50\%; MTT, 3-(4,5-dimethylthiazol-2-yl)-2,5diphenyltetrazolium bromide. 

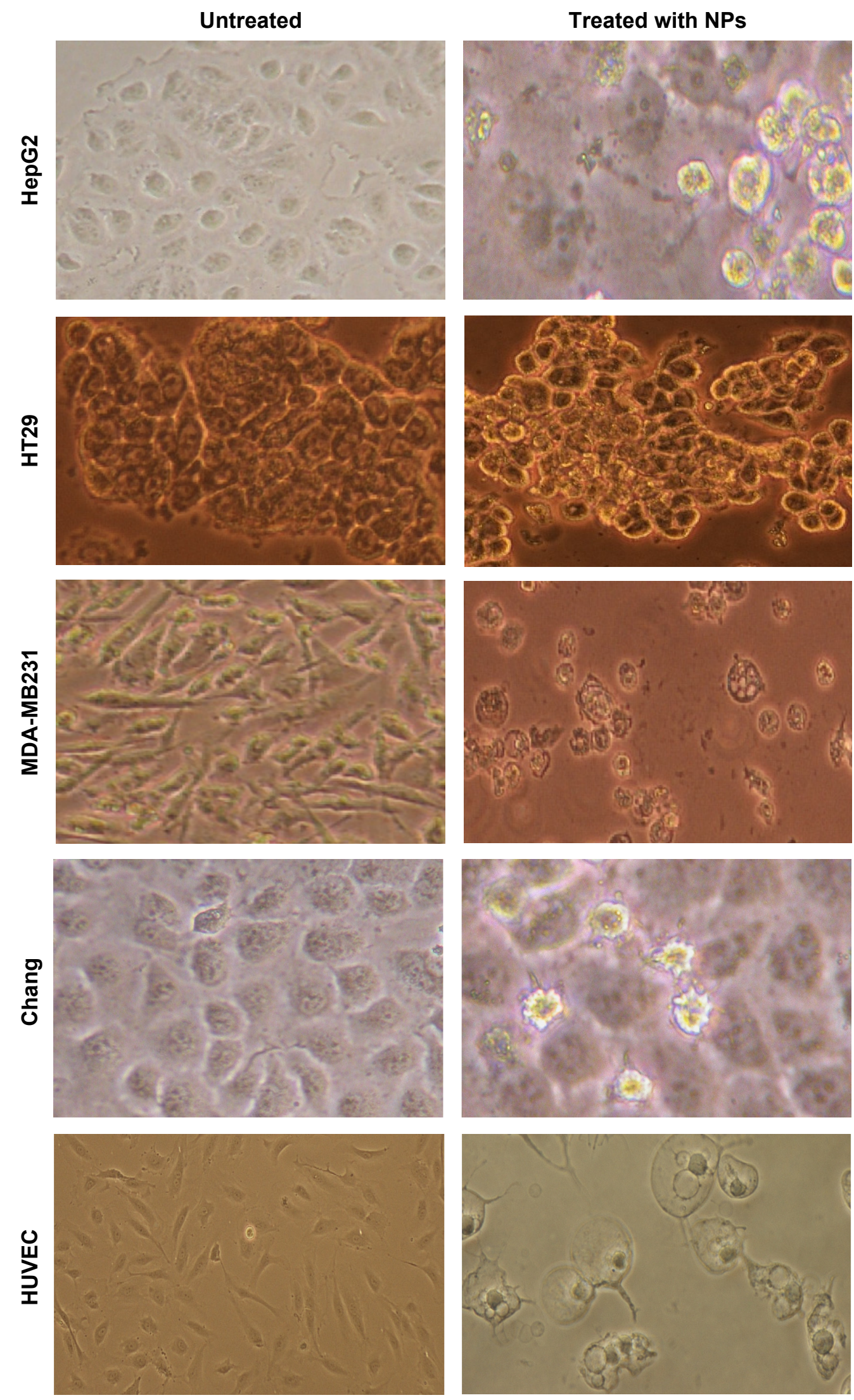

Figure 7 The morphological changes of HepG2 cells, HT29 cells, MDD-MB23I cells, Chang cells, and HUVECs treated with iron-manganese-promoted sulfated zirconia nanoparticles at their respective $\mathrm{IC}_{50}$ concentrations for 72 hours..

Abbreviations: HUVEC, human umbilical vein endothelial cell; $I C_{50}$, concentration of drug needed to inhibit cell growth by $50 \%$; NPs, nanoparticles. 
tested cancer cells. These findings highlight the potential of iron-manganese-doped sulfated zirconia nanoparticles in the treatment of cancer. However, there is a need to study their effect in vivo to ascertain whole-body efficacy and/or any side effects.

\section{Acknowledgments}

The authors would like to thank the Institute of Bioscience and PUTRACAT Laboratories, Universiti Putra Malaysia, for their generous support and help during the experimental work.

\section{Disclosure}

The authors declare no conflicts of interest in this work.

\section{References}

1. Reddy BM, Patil MK. Organic syntheses and transformations catalyzed by sulfated zirconia. Chem Rev. 2009;109(6):2185-2208.

2. Yadav GD, Nair JJ. Sulfated zirconia and its modified versions as promising catalysts for industrial processes. Microporous Mesoporous Mater. 1999;33(1-3):1-48.

3. Brown ASC, Hargreaves JSJ. Sulfated metal oxide catalysts. Superactivity through superacidity? Green Chem. 1999;1:17-20.

4. Clark JH. Solid acids for green chemistry. Acc Chem Res. 2002; 35(9):791-797.

5. Delahay G, Ensuque E, Coq B, Figuéras F. Selective catalytic reduction of nitric oxide byn-decane on $\mathrm{Cu}$ /sulfated-zirconia catalysts in oxygen rich atmosphere: effect of sulfur and copper contents. J Catal. 1998; 175(1):7-15.

6. Ecormier MA, Wilson K, Lee AF. Structure-reactivity correlations in sulphated-zirconia catalysts for the isomerisation of $\alpha$-pinene. $J$ Catal. 2003;215(1):57-65.

7. Date AA, Patravale VB. Current strategies for engineering drug nanoparticles. Curr Opin Colloid Interface Sci. 2004;9(3-4):222-235.

8. Bond GC. Metal-Catalysed Reactions of Hydrocarbons. New York: Springer; 2006.

9. Hafner A, Braes S. Efficient trifluoromethylation of activated and nonactivated alkenyl halides by using (trifluoromethyl) trimethylsilane. $A d v$ Synth Catal. 2011;353(16):3044-3048.

10. Pissuwan D, Valenzuela SM, Cortie MB. Therapeutic possibilities of plasmonically heated gold nanoparticles. Trends Biotechnol. 2006;24(2):62-67.

11. Thibault-Starzyk F, Stan I, Abelló S, et al. Quantification of enhanced acid site accessibility in hierarchical zeolites - the accessibility index. J Catal. 2009;264(1):11-14.

12. Carniti P, Gervasini A, Marzo M. Absence of expected side-reactions in the dehydration reaction of fructose to HMF in water over niobic acid catalyst. Catal Commun. 2011;12(12):1122-1126.

13. Chizallet $C$, Raybaud P. Pseudo-bridging silanols as versatile Brønsted acid sites of amorphous aluminosilicate surfaces. Angew Chem Int Ed Engl. 2009;48(16):2891-2893.

14. Dong S, Han C, Zheng B, Zhang M, Huang F. Preparation of two new [2]rotaxanes based on the pillar[5] arene/alkane recognition motif. Tetrahedron Lett. 2012;53(28):3668-3671.

15. Kašpar J, Fornasiero P. Nanostructured materials for advanced automotive de-pollution catalysts. $J$ Solid State Chem. 2003;171(1-2):19-29.

16. Kuhn JN, Huang W, Tsung CK, Zhang Y, Somorjai GA. Structure sensitivity of carbon-nitrogen ring opening: impact of platinum particle size from below 1 to $5 \mathrm{~nm}$ upon pyrrole hydrogenation product selectivity over monodisperse platinum nanoparticles loaded onto mesoporous silica. J Am Chem Soc. 2008;130(43):14026-14027.
17. Trovarelli A, Zamar F, Llorca J, de Leitenburg C, Dolcetti G, Kiss JT. Nanophase fluorite-structured $\mathrm{CeO} 2-\mathrm{ZrO} 2$ catalysts prepared by highenergy mechanical milling. J Catal. 1997;169(2):490-502.

18. Yan J, Yu D, Li H, Sun P, Huang H. NaY zeolites modified by $\mathrm{La}^{3+}$ and $\mathrm{Ba}^{2+}$ : the effect of synthesis details on surface structure and catalytic performance for lactic acid to acrylic acid. Journal of Rare Earths. 2010; 28(5):803-806.

19. Zhou L, Xu J, Li X, Wang F. Metal oxide nanoparticles from inorganic sources via a simple and general method. Mater Chem Phys. 2006;97(1):137-142.

20. Aghapoor K, Ebadi-Nia L, Mohsenzadeh F, Mohebi Morad M, Balavar Y, Darabi HR. Silica-supported bismuth(III) chloride as a new recyclable heterogeneous catalyst for the Paal-Knorr pyrrole synthesis. J Organomet Chem. 2012;708-709:25-30.

21. Liu C, Wang J, Li Y. One-pot synthesis of 3,4-dihydropyrimidin-2$(1 \mathrm{H})$-(thio)ones using strontium(II) nitrate as a catalyst. J Mol Catal A Chem. 2006;258(1-2):367-370.

22. Zou XX, Li GD, Wang YN, et al. Direct conversion of urea into graphitic carbon nitride over mesoporous $\mathrm{TiO} 2$ spheres under mild condition. Chem Commun (Camb). 2011;47(3):1066-1068.

23. Kumar D, Reddy VB, Mishra BG, Rana RK, Nadagouda MN, Varma RS. Nanosized magnesium oxide as catalyst for the rapid and green synthesis of substituted 2-amino-2-chromenes. Tetrahedron. 2007;63(15):3093-3097.

24. Yan W, Wang R, Xu Z, et al. A novel, practical and green synthesis of Ag nanoparticles catalyst and its application in three-component coupling of aldehyde, alkyne, and amine. J Mol Catal A Chem. 2006;255(1-2):81-85

25. Naik MA, Mishra BG, Dubey A. Combustion synthesized $\mathrm{WO}_{3}-$ $\mathrm{ZrO}_{2}$ nanocomposites as catalyst for the solvent-free synthesis of coumarins. Colloids Surf A Physicochem Eng Asp. 2008;317(1-3): 234-238.

26. Samantaray S, Hota G, Mishra BG. Physicochemical characterization and catalytic applications of $\mathrm{MoO}_{3}-\mathrm{ZrO}_{2}$ composite oxides towards one pot synthesis of amidoalkyl naphthols. Catal Commun. 2011; 12(13):1255-1259.

27. Zhang X, Du AJ, Lee P, Sun DD, Leckie JO. Grafted multifunctional titanium dioxide nanotube membrane: separation and photodegradation of aquatic pollutant. Appl Catal B. 2008;84(1-2):262-267.

28. Katada N, Endo J, Notsu K, Yasunobu N, Naito N, Niwa M. Superacidity and catalytic activity of sulfated zirconia. J Phys Chem B. 2000; 104(44): 10321-10328.

29. Reddy BM, Patil MK. Organic syntheses and transformations catalyzed by sulfated zirconia. Chemical reviews. 2009;109(6):2185-2208.

30. Patil MK, Prasad AN, Reddy BM. Zirconia-based solid acids: green and heterogeneous catalysts for organic synthesis. Current Organic Chemistry. 2011;15(23):3961-3985.

31. Song X, Sayari A. Sulfated zirconia-based strong solid-acid catalysts: recent progress. Cat Rev Sci Eng. 1996;38(3):329-412.

32. Al-Qubaisi M, Rosli R, Subramani T, et al. Goniothalamin selectively induces apoptosis on human hepatoblastoma cells through caspase-3 activation. Nat Prod Res. 2013;27(23):2216-2218.

33. Al-Qubaisi M, Rozita R, Yeap SK, Omar AR, Ali AM, Alitheen NB. Selective cytotoxicity of goniothalamin against hepatoblastoma HepG2 cells. Molecules. 2011;16(4):2944-2959.

34. Al-Qubaisi MS, Rasedee A, Flaifel MH, et al. Cytotoxicity of nickel zinc ferrite nanoparticles on cancer cells of epithelial origin. Int J Nanomedicine. 2013;8:2497-2508.

35. Al-Qubaisi MS, Rasedee A, Flaifel MH, et al. Induction of apoptosis in cancer cells by NiZn ferrite nanoparticles through mitochondrial cytochrome C release. Int J Nanomedicine. 2013;8:4115-4129.

36. Mftah A, Alhassan FH, Al-Qubaisi MS, et al. Physicochemical properties, cytotoxicity, and antimicrobial activity of sulphated zirconia nanoparticles. Int J Nanomedicine. 2015;10:765-774.

37. Alhassan FH, Rashid U, Taufiq-Yap YH. Synthesis of waste cooking oil-based biodiesel via effectual recyclable bi-functional $\mathrm{Fe}_{2} \mathrm{O}_{3}-\mathrm{MnO}$ $\mathrm{SO}_{4}{ }^{2-} / \mathrm{ZrO}_{2}$ nanoparticle solid catalyst. Fuel. 2015;142:38-45. 
38. Alhassan FH, Rashid U, Yunus R, Kamaliah S, Ibrahim LM, TaufiqYap YH. Synthesis of ferric-manganese doped tungstated zirconia nanoparticles as heterogeneous solid superacid catalyst for biodiesel production from waste cooking oil. International Journal of Green Energy. 2015;12(9):987-994.

39. Jentoft FC, Hahn A, Kröhnert J, et al. Incorporation of manganese and iron into the zirconia lattice in promoted sulfated zirconia catalysts. J Catal. 2004;224(1):124-137.

40. Alhassan FH, Rashid U, Al-Qubaisi MS, Rasedee A, Taufiq-Yap YH. The effect of sulfate contents on the surface properties of iron-manganese doped sulfated zirconia catalysts. Powder Technol. 2014;253:809-813.

41. Cheng Z, Yang H, Yu L, Cui Y, Feng S. Preparation and magnetic properties of $\mathrm{Y}_{3} \mathrm{Fe}_{5} \mathrm{O}_{12}$ nanoparticles doped with the gadolinium oxide. J Magn Magn Mater. 2006;302(1):259-262.

42. Patterson AL. The Scherrer formula for X-ray particle size determination. The Physical Review. 1939;56(10):978.

43. Drofenik M, Lisjak D, Makovec D. The synthesis and properties of magnetic nanoparticles. Paper presented at: The Materials Science Forum; 2005;494.

44. Scheithauer M, Bosch E, Schubert UA, et al. Spectroscopic and microscopic characterization of iron- and/or manganese-promoted sulfated zirconia. J Catal. 1998;177(1):137-146.

45. Samantaray S, Kar P, Hota G, Mishra BG. Sulfate grafted iron stabilized zirconia nanoparticles as efficient heterogenous catalysts for solventfree synthesis of xanthenediones under microwave irradiation. Ind Eng Chem Res. 2013;52(17):5862-5870.

46. Wu Y, Qin L, Zhang G, Chen L, Guo X, Liu M. Porous solid superacid $\mathrm{SO}_{4}^{2-} / \mathrm{Fe}_{2-\mathrm{x}} \mathrm{Zr}_{\mathrm{x}} \mathrm{O}_{3}$ fenton catalyst for highly effective oxidation of X-3B under visible light. Ind Eng Chem Res. 2013;52(47):16698-16708.

47. Weckhuysen BM, Wang D, Rosynek MP, Lunsford JH. Conversion of methane to benzene over transition metal ion ZSM-5 zeolites: II. Catalyst characterization by X-ray photoelectron spectroscopy. J Catal. 1998;175(2):347-351.
48. Bi M, Li H, Pan WP, Lloyd WG, Davis BH. Thermal studies of metal promoted sulfated zirconia. Preprints of Papers-American Chemical Society, Division of Fuel Chemistry. 1996;41:77-81.

49. Khalaf HA. Textural properties of sulfated iron hydroxide promoted with aluminum. Monatsh Chem. 2009;140(6):669-674.

50. Clearfield A, Serrette GPD, Khazi-Syed AH. Nature of hydrous zirconia and sulfated hydrous zirconia. Catal Today. 1994;20(2):295-312.

51. Mekhemer GAH, Khalaf HA, Mansour SAA, Nohman AKH. Sulfated alumina catalysts: consequences of sulfate content and source. Monatsh Chem. 2005;136(12):2007-2016.

52. Costa AA, Braga PRS, de Macedo JL, Dias JA, Dias SCL. Structural effects of $\mathrm{WO}_{3}$ incorporation on USY zeolite and application to free fatty acids esterification. Microporous Mesoporous Mater. 2012;147(1): $142-148$.

53. Santos JS, Dias JA, Dias SCL, et al. Mixed salts of cesium and ammonium derivatives of 12-tungstophosphoric acid: synthesis and structural characterization. Appl Catal A Gen. 2011;394(1-2):138-148.

54. Yamamoto T, Tanaka T, Takenaka S, et al. Structural analysis of iron and manganese species in iron- and manganese-promoted sulfated zirconia. J Phys Chem B. 1999;103(13):2385-2393.

55. Garvie RC, Goss MF. Intrinsic size dependence of the phase transformation temperature in zirconia microcrystals. J Mater Sci. 1986; 21(4):1253-1257.

56. Butt HJ, Cappella B, Kappl M. Force measurements with the atomic force microscope: technique, interpretation and applications. Surf Sci Rep. 2005;59(1-6):1-152.

57. Li Y, Somorjai GA. Nanoscale advances in catalysis and energy applications. Nano Lett. 2010;10(7):2289-2295.
International Journal of Nanomedicine

\section{Publish your work in this journal}

The International Journal of Nanomedicine is an international, peerreviewed journal focusing on the application of nanotechnology in diagnostics, therapeutics, and drug delivery systems throughout the biomedical field. This journal is indexed on PubMed Central, MedLine, CAS, SciSearch ${ }^{\circledR}$, Current Contents ${ }^{\circledR} /$ Clinical Medicine,

\section{Dovepress}

Journal Citation Reports/Science Edition, EMBase, Scopus and the Elsevier Bibliographic databases. The manuscript management system is completely online and includes a very quick and fair peer-review system, which is all easy to use. Visit http://www.dovepress.com/ testimonials.php to read real quotes from published authors. 